H. V. Bilavych ${ }^{1}$

ORCID https://orcid.org/0000-0002-1555-0932

L. V. Iliichuk ${ }^{1}$

ORCID https://orcid.org/0000-0003-4274-6903

S. B. Malona ${ }^{1}$

ORCID https://orcid.org/0000-0001-5509-9771

B. P. Savchuk ${ }^{1}$

ORCID https://orcid.org/0000-0003-2256-0845

O. Ja. Dovgij ${ }^{1}$

ORCID https://orcid.org/0000-0002-9718-3442

O. Z. Yaremchuk ${ }^{2}$

ORCID https://orcid.org/0000-0001-5951-1137

ResearcherID B-3056-2016

Scopus Author ID 54387620300

\author{
${ }^{1}$ Vasyl Stefanyk Precarpathian National University \\ ${ }^{2}$ I. Horbachevsky Ternopil National Medical University
}

\title{
INNOVATIVE TEACHING METHODS AS A MEANS OF DEVELOPMENT OF GIFTED PERSONALITY (BASED ON THE EXPERIENCE OF THE ACTIVITY OF THE “UNIVERSITY OF THE GIFTED CHILD” AT VASYL STEFANYK PRECARPATHIAN NATIONAL UNIVERSITY)
}

\author{
Г. В. Білавич ${ }^{1}$, Л. В. Ілійчук ${ }^{1}$, С. Б. Мальона ${ }^{1}$, Б. П. Савчук ${ }^{1}$, \\ О. Я. Довгий ${ }^{1}$, О. З. Яремчук
}

${ }^{1}$ Прикарпатський національний університет імені Василя Стефаника

${ }^{2}$ Тернопільський національний медичний університет імені I. Я. Горбачевського МОЗ Украӥни

\section{ІННОВАЦІЙНІ МЕТОДИ НАВЧАННЯ ЯК ЗАСІБ РОЗВИТКУ ОБДАРОВАНОСТІ ОСОБИСТОСТІ (З ДОСВІДУ ДІЯЛЬНОСТІ «УНІВЕРСИТЕТУ ОБДАРОВАНОЇ ДИТИНИ» ПРИКАРПАТСЬКОГО НАЦІОНАЛЬНОГО УНІВЕРСИТЕТУ ІМЕНІ ВАСИЛЯ СТЕФАНИКА)}

\footnotetext{
Abstract. The purpose of the article is to analyze the activities of the "University of the Gifted Child" at Vasyl Stefanyk Precarpathian National University on the development of gifted students through the prism of the use of innovative teaching methods. One of the key tasks of the RMC "University of the Gifted Child" is the development of academic, aesthetic, sports, practical, other types of giftedness of children and scientific and methodological support of this process; creating an appropriate methodological complex on child development, development of classes, didactic material; introduction of experimental and innovative activities, development of information models of education and development of the child, intellectual information environments for educational purposes, etc. Teachers and students build their work with children on the basis of coaching.
}

Key words: "University of the Gifted Child"; innovative teaching methods; coaching; gifted student; development of academic, aesthetic, sports, practical, other types of giftedness.

\begin{abstract}
Анотація. Мета статті - проаналізувати діяльність «Університету обдарованої дитини» Прикарпатського національного університету імені Василя Стефаника щодо розвитку обдарованості школярів крізь призму використання інноваційних методів навчання. Одним із ключових завдань НМЦ «Університет обдарованої дитини» є розвиток академічної, естетичної, спортивної, практичної, інших видів обдарованості дитини і науково-методичний супровід цього процесу, створення відповідного методичного комплексу з проблем розвитку дітей, розроблення занять, дидактичного матеріалу, упровадження експериментальної та
\end{abstract}

(C) H. V. Bilavych, L. V. Iliichuk, S. B. Malona et al. 
інноваційної діяльності, розроблення інформаційних моделей навчання та розвитку дитини, інтелектуальних інформаційних середовищ навчального призначення тощо. Викладачі та студенти будують свою роботу з дітьми на засадах коучингу.

Ключові слова: «Університет обдарованої дитини»; інноваційні методи навчання; коучинг; обдарований студент; розвиток академічної, естетичної, спортивної, практичної обдарованості.

Introduction. One of the most important tasks of Ukraine as a state is to promote the development of young generations, to meet its educational and cultural needs. This is directed by the UN Convention on the Rights of the Child, the Universal Declaration on the Survival, Protection and Development of Children and other documents. A significant role in the implementation of these tasks is played by the timely identification and support of gifted children, the maximum realization of their talents and abilities [1, 2].

Of great importance is the scientific and pedagogical solution to the problem of identifying and developing the creative abilities of the younger generation, the study of the theoretical foundations of an effective state system of support for talented youth [1, p. 10].

For this purpose, the Research and Methodology Center (hereinafter - RMC) "University of the Gifted Child (UGC)" was established at Vasyl Stefanyk Precarpathian National University, the core of which is the Faculty of Pedagogy. The priority areas of work are:

- creation of scientific and methodical bases of formation, support, distribution and use of modern systems of knowledge on subject branches used in educational and cognitive activity of children and youth; - purposeful creation of an educational environment based on the use of modern information and communication and innovative technologies; its functioning is aimed at the implementation of active learning of students in the basics of science, activation of children's cognitive interests, organization of their independent and group cognitive activity, development of associative and creative thinking of students, ingenuity, comprehensive development of the child;

- use of active forms of work with children, modernization of traditional classes into the interactive ones, introduction of innovative technologies and methods;

- development of program-information and information-methodical support of intellectual and aesthetic development of children and youth, management of development of academic talent of schoolchildren;

- development of the essence of synergetic methodology in the formation of a gifted personality: identification of potential creative potential of the child, which cannot be disclosed through the use of traditional methods and techniques;
- development of program-information and information-methodical support of practical intelligence of students;

- formation of national-linguistic personality, etc.

Such design of educational, developmental and social space for children allows optimizing the process of comprehensive development of the child.

The analysis of recent research. The problem of giftedness has been considered by many foreign and Ukrainian scientists in the fields of pedagogy, psychology, philosophy, sociology, physiology, etc. The nature of giftedness, the psyche of gifted children were studied by J. Guilford, Yu. Gilbukh, O. Kulchytska, N. Leites, O. Matyushkin, O. Muzyka, V. Molyako, M. Podyakov, V. Rybalko, G. Tarasova, P. Torrens, V. Yurkevych and others. Scientists have developed psychological and pedagogical principles of creative development of children in primary school (J. Wenger, V. Davydov, D. Elkonin, O. Zaporozhets, V. Klymenko, T. Khromova, etc.), features of teaching gifted children (M. Burgin, N. Dokshyna, S. Koshel, etc.), features of work with gifted children (O. Antonova, O. Gubeko, L. Zhuk, R. Naumenko, etc.). Thus, the analysis of the source base showed that the issue of gifted personality acquired the status of national importance, but the problem stated in the title of the article was not studied in depth by scientists.

The aim - to analyze the activities of the "University of the Gifted Child" at Vasyl Stefanyk Precarpathian National University on the development of gifted students through the prism of the use of innovative teaching methods.

Methods. In research the following research methods are used: general scientific (analysis, synthesis, deduction, induction, comparison, classification, generalization), which allow to argue and justify the experience of using innovative teaching methods in the activities of the "University of the Gifted Child"; search and bibliographic for systematization of research sources; comparative and descriptive - to characterize the activities of the "University of the Gifted Child" on the development of gifted students.

Results. The RMC "University of the Gifted Child" was established on May 29, 2017 at Vasyl Stefanyk Precarpathian National University with the assistance 
of the Rector, Prof. Igor Tsependa. The head of the RMC "University of the Gifted Child” - Professor of Pedagogy of Primary Education H. Bilavych. The main staff of UGC are teachers and students of the Faculty of Pedagogy, including the Department of Pedagogy of Primary Education and Ivano-Frankivsk Vocational College, as well as teachers and students of other departments of the University (Department of Professional Methods and Technologies of Primary Education, Department of Mathematics and Informatics and Teaching Methods, Department of Theory and methods of physical culture and sports, Department of Management and Business Administration, Department of Journalism, etc.). Thus, the project "University of the Gifted Child" (UGC), aimed at the comprehensive development of personality, is being successfully implemented. Thus, in late May - early June 2017, about 90 training workshops were held, which were attended by about 1,000 primary school children and adolescents in Ivano-Frankivsk [5].

Subsequently, this format was continued during the autumn holidays, from October 31 to November 4, 2017, when schools for chess, judo, tennis, make-up and entertainment, journalism, detectives, "Language Ecologists”, IT school, robotics and technical creativity, dance, vocals, playing musical instruments, literary room "Visiting the writer Olha Derkachova", etc. The attractiveness of the project was primarily in the use of innovative methods and forms of education and development of children. In all the actions in which UGC was invited as a team of specialists, both teachers and students worked as volunteers [5].

The School of Inventors, headed by Roman Tkachuk, Head of the Training and Technical Center of the Department of Solid State Physics and Chemistry, Faculty of Physics and Technology of Vasyl Stefanyk Precarpathian National University, is aimed at developing students' technical talent. It is based on the innovative teaching methods, while modeling and technological activity of young students of UGC is the cornerstone of its activity.

The School of Language Ecologists, the School of Rhetoricians, the Literary Room, the School of Acting, the School of Polyglots, etc. are aimed at the development of students' speech culture. The main activities of the School of Language Ecologists and the School of Rhetoricians (headed by $\mathrm{H}$. Bilavych and students of the "Language Ecologists" group) are the idea of creating a "language-ecological environment" for the UGC participants, which for various reasons cannot be created under school conditions. In the process of subject-subject interaction "teacher - student - pupil” creates an "environmentally friendly language environment", in which due to the transfer of knowledge and experience in children and students the level of oral culture increases [4]. To form a clean language environment, ecological expeditions were conducted on the streets of Ivano-Frankivsk. Visiting public institutions and shops, schoolchildren learned to track typical language errors. For example, classes in the café "PersheDruhe" were of great cognitive and educational value, where young students of UGC learned the vocabulary of life and food, practiced etiquette formulas of greetings, farewells, requests, thanks, apologies, etc. During the competition "Who is more..." in the institution, the members competed in fixing as many speech errors as they could find in the speech of friends and employees and visitors of the cafe. At the next class in the UGC on the basis of these records concluded a common minidictionary with typical violations of vocabulary and word usage. In continuation of this work, students performed homework to compile a dictionary-reference book for family use on normative word usage in the field of household vocabulary. This dictionary can be used for family members, peers, to disseminate relevant information through social networks (groups, blogs) [6]. The acquired speech, literary and oratory skills and abilities are demonstrated by young students of UGC at the organized competitions of readers, during quizzes, holidays. Thus, the annual grand opening and closing of the project "Interesting Vacation" has already become traditional. Scenarios for them are created by schoolchildren, students, teachers, and the celebrations are held by the children themselves [9, p. 203].

Over the years of the UGC's activity (2017-2020) the content of the educational and developmental program "Interesting Holidays" from UGC for children has become even broader and more diverse [5-8]. Thus, in 2020, in connection with the spread of COVID-19 in Ukraine, UGC has prepared a diverse online curriculum. It has become an out-of-school institution for children, where an online space for comprehensive personal development for schoolchildren was organized by a highly professional teaching staff, talented students, as well as Vasyl Stefanyk Precarpathian National University graduates, who have been participating in the project since its inception.

Teachers and students actively implement the ideas of the "New Ukrainian School” concept, use interdisciplinary links, conduct integrated classes, use innovative teaching methods, etc., based on the principles of coaching. Here are some examples of the innovation 
activity. Thus, for three days in June 2020, a team of volunteers conducted classes on Zoom platform in the following areas: educational and developmental (School of Creative Ideas "Happy Hobby”); physical and health (Olympic Reserve School, "Visiting a doctor"); artistic (School of Painting, School of Skillful Hands, School of Dance); general technical (Ecoschool, etc.); etc.

The school of the art cycle "Skillful Hands" (head Associate Professor of Pedagogy of Primary Education Oksana Tsyunyak) offered children two online classes: "Harmony of creativity. The fabric application "Tree of Happiness" and the master class "My colored stone" conducted by student volunteers. The materials for the work were fabric of different textures; it was used to create applications. The technique of drawing in a non-standard way "My colored stone" was just as interesting for children. Young UGC students learned that even ordinary stones can be turned into a work of art. Decorated stones can not only decorate the interior, but also be a good gift (University of the Gifted Child, 2020).

The butterfly drawing master class, conducted by Mykhailo Hnatyuk, associate professor of the Department of Professional Methods and Technologies of Primary Education, was a great opportunity to create a beautiful picture that you can give as present to your friends.

The School of Creative Ideas “Happy Hobby” (head Associate Professor of Pedagogy of Primary Education Lyubomyra Iliychuk) demonstrated to children creative techniques of drawing on water based on an interdisciplinary approach. In addition to drawing, young UGC students observed interesting experiments and also made paper flowers that "bloom on water" [8].

All the classes were conducted by students along with teachers.

In Ecoschool (head - Associate Professor of Professional Methods and Technologies of Primary Education Lesya Vysochan), Vocal School (head - Professor of Pedagogy of Primary Education Maria Klepar), School of Polyglots (heads - PhD student Andrii Savchuk, graduate student Natalia Holovchak), School of Giftedness Diagnostics - Associate Professor of Social Pedagogy and Social Work Oksana Protas), Literary Room (heads - professors of the Department of Pedagogy of Primary Education - Natalia Blagun and Olha Derkachova), School of Business and Economics (heads - associate professors of Management and Business Administration - Olha Zhuk amd Antonina, Tomashevska), School of Interesting Mathema- tics (head - Associate Professor of Professional Methods and Technologies of Primary Education Ruslana Romanyshyn), School of Noble Ukrainian Women (heads - PhD student Maria Bagriy, Associate Professor of Pedagogy of Primary Education Iryna Humeniuk), the UGC Scientific Society (head - Professor of Pedagogy and Educational Management Borys Savchuk), etc., both traditional learning technologies (explanatory-illustrative, problem-based, programmable, differentiated, etc.) and new learning technologies (personality-oriented, group, developmental, creative personality formation technologies, learning technologies as research, new information technologies, etc.) are being widely used.

Children's physical activity is very important when classes are held online. Therefore, the organizers of the project strive to schedule classes so that children have daily activities aimed at physical development. For example, on Monday they attend Dance School, on Tuesday, Thursday - Olympic Reserve School. The sports class, conducted by an experienced teacher, Associate Professor of the Theory and Methods of Physical Culture and Sports, Master of Sports of Ukraine in Judo Svitlana Malona and athlete, certified nutritionist, boxing coach Nazar Durkalo, was liked by boys and girls who willingly performed a set of physical exercises. Children note that such classes with famous athletes are much more interesting than a regular physical education class at school [8].

The School of Logic under the guidance of Associate Professor of Pedagogy and Methods of Primary Education Oleh Dovhyi, among other things, is aimed at forming students' interest in mathematics, the development of logic and more. Thanks to the use of interesting games, crosswords, puzzles, various tasks younger students and adolescents primarily develop their interest in mathematics, overcome the stereotype of mathematics as a school subject ("complex mathematics", "uninteresting mathematics", "boring mathematics" and so on). Classes at the School of Interesting Mathematics together with the teacher are conducted not only by students of Vasyl Stefanyk Precarpathian National University, but also by students of Ivano-Frankivsk Vocational College. The classes teach mathematics (in combination with logic and geometry) in the form of a game [3].

Within the activities of the IT school (head - Associate Professor of Mathematics and Informatics and Teaching Methods Olesia Vlasiy) the idea of creating an online dating board of the UGC team and a map of UGC 2020 participants was implemented. A number of interesting competitions and workshops were aimed 
at forming IT competence of students, using computer technology (educational quest from the fairy-tale hero Language Cleaner; Language Cleaner is an expert in literacy, who always cares about the purity of speech and spelling; master class "My first computer game", where students together with their parents had the opportunity to create their own first computer football game), etc. [6].

Conclusions and Prospects for Research. Thus, one of the key tasks of the RMC "University of the Gifted Child" is: the development of academic, aesthetic, sports, practical, other types of giftedness of children and scientific and methodological support of this process; creating an appropriate methodological complex on child development, development of

\section{List of literature}

1. Антонова О. Є. Обдарованість: досвід історичного та порівняльного аналізу : монографія / О. Є. Антонова. Житомир : Житомир. держ. ун-т, 2005. - 456 с.

2. Васильченко Л. І. Психолого-педагогічні особливості обдарованих дітей / Л. І. Васильченко // Педагогіка і психологія: вісник АПН України. - 2007. - № 4. С. 32-39.

3. Довгий О. Формування інтересу до математики в учнів у закладах позашкільної освіти / О. Довгий // Молодь і ринок. - 2020. - № 5 (184). - С. 72-76.

4. Савчук Б. Коучинг як філософія і технологія розвитку професійної педагогічної освіти / Б. Савчук, Г. Білавич, Ю. Душенко // Гірська школа Українських Карпат. - 2019. - № 21. - С. 82-87.

\section{References}

1. Antonova, O.E. (2005). Obdarovanist: dosvid istorychnoho ta porivnialnoho analizu [Giftedness: experience of historical and comparative analysis]. Zhytomyr: Zhytomyr. derzh. un-t [in Ukrainian].

2. Vasylchenko, L.I. (2007). Psykholoho-pedahohichni osoblyvosti obdarovanykh ditei [Psychological and pedagogical features of gifted children]. Pedahohika i psykholohiia: visnyk APN Ukrainy - Pedagogy and psychology: Bulletin of the Academy of Pedagogical Sciences of Ukraine, 4, 32-39 [in Ukrainian].

3. Dovhyi, O. (2020). Formuvannia interesu do matematyky v uchniv u zakladakh pozashkilnoi osvity [Formation of students' interest in mathematics at extracurricular educational institutions]. Molod i rynok - Youth and Market, 5 (184), $72-76$ [in Ukrainian].

4. Savchuk, B., Bilavych, H., \& Dushenko, Yu. (2019). Kouchynh yak filosofiia i tekhnolohiia rozvytku profesiinoi pedahohichnoi osvity [Coaching as philosophy and

technology of development professional pedagogical education]. Hirska shkola Ukrainskykh Karpat - Mountain School of the Ukrainian Carpathians, 21, 82-87 [in Ukrainian].

5. University of Gifted Child. 2017. Retrieved from: https://kidsuniver.blogspot.com [in Ukrainian].

6. University of Gifted Child. 2018. Retrieved from: https://pnu.edu.ua > blog > 2018/06/14 > [in Ukrainian].

7. University of Gifted Child. 2019. Retrieved from: https://kidsuniver.blogspot.com [in Ukrainian].

8. University of Gifted Child. 2020. Retrieved from: https://kidsuniver.blogspot.com [in Ukrainian].

9. Savchuk, B., Pantyuk, T., Kotenko, R., Tkachivska, I., Vysochan, L., Pustovit, H.V., ... Fedchyshyn, N. (2020). The usage of coaching technology in the formation of emotional intelligence of future tourism managers. International Journal of Applied Exercise Physiology, 9 (8), 202-210.

Received 11.05.21

Recommended 14.05.21 